\title{
Analysis of trauma patients with unplanned returns to the operating room
}

Areg Grigorian ${ }^{1}$, Sebastian Schubl ${ }^{1}$, Viktor Gabriel ${ }^{1}$, Austin Dosch ${ }^{1}$, Victor Joe ${ }^{1}$, Nicole Bernal ${ }^{1}$, Taimoore Dogar ${ }^{1}$, Jeffry Nahmias ${ }^{1}$

${ }^{1}$ University of California, Irvine, Surgery, Orange, USA

\section{ABSTRACT}

Objective: Trauma patients undergoing damage-control surgery may have a planned return to the operating room. In contrast, little is known about unplanned returns to the operating room (UROR) in trauma. The aim of this study was to identify risk factors for uROR in trauma patients. It is hypothesized that blunt trauma patients with uROR have higher mortality when compared to penetrating trauma patients with uROR. Additionally, it is hypothesized that trauma patients with uROR after thoracotomy have higher mortality than patients with uROR after laparotomy.

Material and Methods: A retrospective analysis of the National Trauma Data Bank from 2011-2015 including any adult patient with an uROR was performed.

Results: From 3.447.320 patients, $9.269(0.2 \%)$ were identified to have uROR. In a multivariable logistic regression analysis, 27 independent predictors were identified for risk of UROR with the strongest independent risk factor being compartment syndrome ( $O R=10.50, C l=9.35-11.78, p<0.001)$. Blunt (compared to penetrating) mechanism was associated with higher risk for mortality in patents with $\mathrm{UROR}(\mathrm{OR}=1.69, \mathrm{Cl}=1.14-2.51, \mathrm{p}<0.001)$ as was reincision thoracotomy (RT) compared to re-incision laparotomy ( $R L)(O R=2.22, C l=1.29-3.84, p<0.001)$.

Conclusion: The strongest risk factor for UROR in trauma is compartment syndrome. Both a blunt (compared to penetrating) mechanism and RT (compared to RL) are independent risk factors for mortality in patients undergoing an uROR.

Keywords: Unplanned return to the operating room, return to the operating room, re-incision thoracotomy, re-incision laparotomy, trauma

Cite this article as: Grigorian A, Schubl S, Gabriel V, Dosch A, Joe V, Bernal N, et al. Analysis of trauma patients with unplanned returns to the operating room. Turk J Surg 2019; $35(1): 54-61$

\section{Corresponding Author}

Areg Grigorian

E-mail: agrigori@uci.edu

Received: 09.04.2018

Accepted: 08.08 .2018

Available Online Date: 01.03 .2019

OCopyright 2019 by Turkish Surgical Society Available online at www.turkjsurg.com

DOI: $10.5578 /$ turkjsurg.4182

\section{INTRODUCTION}

A return to the operating room is associated with worse outcomes in surgical patients (1). Up to $50 \%$ of elective thoracic cases with a return to the operating room are related to technical failures with $27.3 \%$ requiring control of post-operative hemorrhage. These patients have a mortality rate of $5.6 \%$ (2). General surgery patients have been shown to have an unplanned return to the operating room (UROR) rate of $5.9 \%$ with a mortality rate as high as $33.7 \%$. Up to $70 \%$ of UROR in general surgery patients may be related to surgical complications (3). Trauma patients undergoing damage control surgery often have a planned return to the operating room (4). However, the incidence and outcomes of UROR in the trauma population using a large national database has not previously been reported.

The kinematics of blunt trauma and the transfer of energy to the patient are fundamentally different than in penetrating trauma. The larger surface area over which the energy is dispersed can lead to widespread injury and increased severity compared to the localized destruction from penetrating trauma (5). Additionally, trauma patients that have suffered thoracic injuries have a higher rate of mortality particularly with a blunt mechanism of injury (6). Our primary objective was to identify risk factors for $U R O R$ in trauma patients. Additionally, it is hypothesized that blunt trauma patients with UROR have higher mortality when compared to penetrating trauma patients with $\mathrm{UROR}$. Finally, it is hypothesized that trauma patients with UROR for re-incision thoracotomy (RT) have higher mortality than patients with uROR for re-incision laparotomy (RL). 


\section{MATERIAL and METHODS}

This work was approved by the institutional review board of the University of California, Irvine. Informed consent was not necessary as this study involves a large national database with de-identified information. The National Trauma Data Bank (NTDB) is a multicenter registry of trauma centers in the United States maintained by the American College of Surgeons Committee on Trauma (7). All registered cases with $U R O R$ in the NTDB occurring between 2011-2015 were identified. Patients under 18 years of age were excluded. Trauma patients with UROR were compared to those without UROR. The primary outcome was mortality. Secondary outcomes evaluated included total hospital length of stay (LOS), intensive care unit (ICU) LOS, ventilator days, acute kidney injury $(A K I)$, acute respiratory distress syndrome (ARDS), myocardial infarction (MI), pulmonary embolism (PE), deep vein thrombosis (DVT), pneumonia, cerebrovascular accident (CVA), urinary tract infection (UTI), compartment syndrome, severe sepsis, and surgical site infection (SSI). The relation between mortality and baseline patient demographics, comorbidities, injury profile, interventions and hospital outcomes including complications was analyzed.

Patient demographic information including age, gender and prehospital comorbidities were collected. Injury profile included the injury severity score (ISS), mechanism of injury and associated solid organ and extremity injuries. The interventions analyzed included RL and RT based on the appropriate International Classification of Diseases Version-9 procedure codes.

Student's t-test and Mann-Whitney $U$ test were used to compare continuous variables and chi-square was used to compare categorical variables for bivariate analysis. Categorical data were reported as percentages, and continuous data were reported as medians with interquartile range. The magnitude of the association between predictor variables and primary outcomes was measured using a univariable logistic regression model. Covariates with statistical significance $(p \leq 0.20)$ were selected into a multivariable logistic regression model. Confounding variables were controlled for using a hierarchical logistic regression model and risk analysis was reported with an odds ratio (OR) and 95\% confidence intervals $(\mathrm{Cl})$. The reference group used in our logistic regression analysis to identify risk factors for $U R O R$ included all trauma patients in the dataset while the reference group for risk of mortality included only patients with uROR. All $p$ values were two-sided, with a statistical significance level of $<0.05$. All statistical analyses were performed with IBM SPSS Statistics for Windows, Version 24. (IBM Corporation, Armonk, USA).

\section{RESULTS}

\section{Patient Demographics, Injury Profile and Primary Outcomes}

From 3.447 .320 patients, 9.269 (0.2\%) were identified to have UROR with more occurring in penetrating traumas (0.67\%) and less in blunt traumas (0.22\%). There was an increased incidence of UROR for each consecutive year from $0.11 \%$ in 2011 to $0.31 \%$ in $2015(p<0.05)$. When compared to trauma patients without UROR, those with UROR were younger (median age, 45 vs. 50, $\mathrm{p}<0.001$ ) and had a higher median ISS (18.0 vs 6.0, $\mathrm{p}<0.001$ ). Majority of the patients in both groups were involved in blunt trauma. Trauma patients with UROR had higher rates of penetrating mechanism (25.2\% vs. $10.2 \%, \mathrm{p}<0.001)$, hypotension on admission (10.4\% vs. 2.9\%, $\mathrm{p}<0.001)$ and all associated injuries analyzed except for burn injury (1.3\% vs. 2.3\%, p< 0.001) (Table 1). Mortality rate was also higher in patients with UROR (11.8\% vs. $3.7 \%, \mathrm{p}<0.001)$ and higher in patients with RT compared to RL (30.3\% vs. 21.0\%, p<0.05) (Table 2).

\section{Logistic Regression Analysis for Risk of UROR in Trauma Patients}

In a multivariable logistic regression analysis, twenty-seven independent predictors were identified for risk of UROR in trauma patients. The strongest independent risk factors, in order, included compartment syndrome $(\mathrm{OR}=10.50, \mathrm{Cl}=9.35-11.78, \mathrm{p}<0.001)$, $\mathrm{SSI}(\mathrm{OR}=5.44, \mathrm{Cl}=4.82-6.14, \mathrm{p}<0.001)$, severe sepsis $(\mathrm{OR}=3.05$, $\mathrm{Cl}=2.75-3.37, \mathrm{p}<0.001)$ and colorectal injury $(\mathrm{OR}=3.00, \mathrm{Cl}=2.74$ $3.28, p<0.001)$. Patients with a blunt mechanism had a lower risk for $U R O R$ compared to those with a penetrating mechanism $(\mathrm{OR}=0.44, \mathrm{Cl}=0.41-0.47, \mathrm{p}<0.001)$. Patients that were $\geq 65$ years of age also had a lower risk of $\mathrm{UROR}(\mathrm{OR}=0.83, \mathrm{Cl}=0.78-0.88, \mathrm{p}<$ 0.001) (Table 3).

\section{Logistic Regression Analysis for Risk of Mortality in Patients with uROR}

In a multivariable logistic regression analysis, nine independent predictors were identified for risk of mortality in trauma patients with $\mathrm{UROR}$. The strongest independent risk factors, in order, included MI (OR=6.49, Cl=2.19-19.27, $\mathrm{p}<0.05), \mathrm{CHF}(\mathrm{OR}=5.32, \mathrm{Cl}=$ 2.07-13.69, $\mathrm{p}<0.05), \mathrm{AKI}(\mathrm{OR}=3.96, \mathrm{Cl}=2.84-5.50, \mathrm{p}<0.001)$ and age $\geq 65$ years $(\mathrm{OR}=3.66, \mathrm{Cl}=2.47-5.42, \mathrm{p}<0.001)$. Blunt (compared to penetrating) mechanism was associated with higher risk for mortality in patents with $\mathrm{UROR}(\mathrm{OR}=1.69, \mathrm{Cl}=1.14-2.51$, $\mathrm{p}<0.001)$ as was $\mathrm{RT}$ (compared to $\mathrm{RL})(\mathrm{OR}=2.22, \mathrm{Cl}=1.29-3.84$, $\mathrm{p}<0.001$ ) (Table 4).

\section{Secondary Outcomes in Trauma Patients with uROR}

Compared to trauma patients without UROR, those with UROR had a longer LOS (18.0 vs. 3.0 days, $p<0.001$ ), ICU LOS (10.0 vs. 3.0 days, $p<0.001)$ and higher rates of all in-hospital complications analyzed (Table 5).

\section{DISCUSSION}

This retrospective analysis, encompassing five years of NTDB data, provides an analysis of trauma patients undergoing $U R O R$. The incidence of UROR has increased each year from 2011 to 2015 but remains low at $0.31 \%$ in the most recent year analyzed. Majority of the patients were involved in a blunt mechanism of 
Table 1. Demographics and injury profile of trauma patients with and without an unplanned return to the operating room

\begin{tabular}{|c|c|c|c|}
\hline Characteristic & $\begin{array}{c}- \text { uROR } \\
(n=3.438 .051)\end{array}$ & $\begin{array}{c}+ \text { uROR } \\
(n=9269)\end{array}$ & $\mathbf{p}$ \\
\hline Age, year, median (IQR) & $50.0(37)$ & $45.0(32)$ & $<0.001$ \\
\hline Sex (male), n (\%) & $2.158 .458(62.8 \%)$ & $7042(76.0 \%)$ & $<0.001$ \\
\hline \multicolumn{4}{|l|}{ Comorbidities, n (\%) } \\
\hline Congestive heart failure & $107.411(3.1 \%)$ & $31(2.5 \%)$ & $<0.001$ \\
\hline Cerebrovascular accident & $76.189(2.2 \%)$ & $177(1.9 \%)$ & $<0.001$ \\
\hline Diabetes & $404.651(11.8 \%)$ & $1048(11.3 \%)$ & 0.17 \\
\hline Hypertension & $993.094(28.9 \%)$ & $2443(26.4 \%)$ & $<0.001$ \\
\hline COPD & $249.607(7.3 \%)$ & $648(7.0 \%)$ & 0.32 \\
\hline ISS, median (IQR) & $6.0(7)$ & $18.0(16)$ & $<0.001$ \\
\hline Blunt mechanism, n (\%) & $2.860 .547(89.8)$ & $6544(74.8 \%)$ & $<0.001$ \\
\hline Penetrating mechanism, n (\%) & $326.570(10.2 \%)$ & $2208(25.2 \%)$ & $<0.001$ \\
\hline Hypotensive on admission (SBP < 90 mm Hg), n (\%) & 99.204 (2.9\%) & 965 (10.4\%) & $<0.001$ \\
\hline \multicolumn{4}{|l|}{ Injuries, n (\%) } \\
\hline Traumatic brain injury & $1.025 .301(29.8 \%)$ & 3337 (36.0\%) & $<0.001$ \\
\hline Spine & $562.750(16.4 \%)$ & 2581 (27.8\%) & $<0.001$ \\
\hline Rib & 522.407 (15.2\%) & 2505 (27.0\%) & $<0.001$ \\
\hline Upper extremity & 618.191 (18.0\%) & 2245 (24.2\%) & $<0.001$ \\
\hline Lower extremity & $808.142(23.5 \%)$ & $2630(28.4 \%)$ & $<0.001$ \\
\hline Lung & 411.564 (12.0\%) & 2779 (30.0\%) & $<0.001$ \\
\hline Liver & $85.203(2.5 \%)$ & $1190(12.8 \%)$ & $<0.001$ \\
\hline Spleen & $87.965(2.6 \%)$ & 1196 (12.9\%) & $<0.001$ \\
\hline Esophagus & $1368(0.1 \%)$ & $32(0.3 \%)$ & $<0.001$ \\
\hline Stomach & $8752(0.3 \%)$ & $349(3.8 \%)$ & $<0.001$ \\
\hline Small intestine & $28.778(0.8 \%)$ & $1078(11.6 \%)$ & $<0.001$ \\
\hline Colorectal & $26.260(0.8 \%)$ & $1188(12.8 \%)$ & $<0.001$ \\
\hline Pancreas & $2617(0.1 \%)$ & $172(1.9 \%)$ & $<0.001$ \\
\hline Kidney & $44.193(1.3 \%)$ & $646(7.0 \%)$ & $<0.001$ \\
\hline Burn & 79.294 (2.3\%) & $117(1.3 \%)$ & $<0.001$ \\
\hline Crush & $13.298(0.4 \%)$ & $101(1.1 \%)$ & $<0.001$ \\
\hline
\end{tabular}

Table 2. Mortality rates of adult trauma patients

\begin{tabular}{|l|c|}
\hline Population & Mortality, \% \\
\hline UROR & $11.8 \%$ \\
\hline No UROR & $3.7 \%$ \\
\hline Re-incision thoracotomy & $30.3 \%$ \\
\hline Re-incision laparotomy & $21.0 \%$ \\
\hline \multicolumn{2}{|l|}{ UROR: Unplanned return to the operating room. } \\
\hline
\end{tabular}

injury. Multiple predictors were identified for risk of UROR but the strongest risk factor was compartment syndrome. In support of our hypothesis, it was demonstrated that both a blunt (compared to penetrating) mechanism and RT (compared to RL) are independent risk factors for mortality in patients undergoing an UROR.

Trauma patients with UROR have multiple injuries, which may not all be clinically apparent during primary/secondary surveys. We identified higher rates of nearly all associated injuries 


\begin{tabular}{|c|c|c|c|}
\hline Predictor & OR & $95 \% \mathrm{Cl}$ & $\mathrm{p}$ \\
\hline Blunt vs. penetrating mechanism & 0.44 & $0.41-0.47$ & $<0.001$ \\
\hline Age $\geq 65$ & 0.83 & $0.78-0.88$ & $<0.001$ \\
\hline Upper extremity injury & 1.07 & $1.01-1.13$ & $<0.05$ \\
\hline Diabetes & 1.11 & $1.03-1.20$ & $<0.05$ \\
\hline Lung injury & 1.16 & $1.09-1.24$ & $<0.001$ \\
\hline Kidney injury & 1.17 & $1.06-1.29$ & $<0.05$ \\
\hline Myocardial infarction-complication & 1.17 & $1.23-1.77$ & $<0.001$ \\
\hline Hypotensive on admission & 1.19 & $1.10-1.29$ & $<0.001$ \\
\hline Hypertension-comorbidity & 1.22 & $1.15-1.29$ & $<0.001$ \\
\hline Spine injury & 1.24 & $1.18-1.31$ & $<0.001$ \\
\hline Liver injury & 1.25 & $1.15-1.35$ & $<0.001$ \\
\hline Traumatic brain injury & 1.28 & $1.22-1.35$ & $<0.001$ \\
\hline Pancreas injury & 1.29 & $1.06-1.29$ & $<0.05$ \\
\hline Lower extremity injury & 1.37 & $1.31-1.45$ & $<0.001$ \\
\hline Male gender & 1.39 & $1.32-1.47$ & $<0.001$ \\
\hline Stomach injury & 1.46 & $1.27-1.67$ & $<0.001$ \\
\hline Pulmonary emboli-complication & 2.03 & $1.78-2.32$ & $<0.001$ \\
\hline Acute kidney injury-complication & 2.11 & $1.91-2.33$ & $<0.001$ \\
\hline Esophagus injury & 2.13 & $1.44-3.14$ & $<0.001$ \\
\hline Urinary tract infection-complication & 2.25 & $2.06-2.45$ & $<0.001$ \\
\hline ISS $>25$ & 2.26 & $2.12-2.41$ & $<0.001$ \\
\hline Small intestine injury & 2.55 & $2.33-2.79$ & $<0.001$ \\
\hline Deep vein thrombosis-complication & 2.62 & $2.40-2.86$ & $<0.001$ \\
\hline Crush injury & 2.63 & $2.11-3.30$ & $<0.001$ \\
\hline Pneumonia-complication & 2.81 & $2.62-3.01$ & $<0.001$ \\
\hline Colorectal injury & 3.00 & $2.74-3.28$ & $<0.001$ \\
\hline Severe sepsis-complication & 3.05 & $2.75-3.37$ & $<0.001$ \\
\hline Surgical site infection & 5.44 & $4.82-6.14$ & $<0.001$ \\
\hline Compartment syndrome & 10.50 & $9.35-11.78$ & $<0.001$ \\
\hline
\end{tabular}

analyzed except for burn injuries in patients with UROR. Injury profile coupled with more severe trauma experienced by patients with UROR likely provided the "perfect-storm" for occult and missed injuries, which may have presented later requiring UROR. This is particularly true in patients with TBI or spine injury since these patients often have unreliable clinical exams $(8,9)$. False-negative rates may continue to be high on subsequent exams. Houshian et. al have performed a retrospective analysis over four years at a Level-1 trauma center and found that $14 \%, 38 \%$ and $48 \%$ of injuries are missed in primary, secondary and tertiary surveys, respectively (10). In support of these reports, it was found in the present study that UROR had significantly higher rates of TBI and spine injury. Additionally, trauma patients with TBI were found to have a $28 \%$ increased risk for UROR while those with spine injury have a $24 \%$ increased risk for $U R O R$. However, the most significant risk factor for $U R O R$ was compartment syndrome. This complication is unique because diagnosis is often made clinically without any widespread, highly sensitive or specific imaging or diagnostic modalities to help clinicians. Vigilance and good clinical judgment, especially determining the need for a prophylactic fasciotomy remain the hallmarks of management (11). The difficulty in diagnosing patients correctly may be responsible for the high risk of uROR. For this reason, almost $90 \%$ of cases involving compartment syndrome that reach litigation have a delay in diagnosis (12). 
Table 4. Multivariable analysis for risk of mortality in adult trauma patients with an unplanned return to operating room

\section{Predictor}

Deep vein thrombosis-complication Urinary tract infection-complication

Pulmonary emboli-complication

Pneumonia-complication

Blunt vs. penetrating mechanism

ARDS-complication

ISS $\geq 25$

Re-incision thoracotomy vs. re-incision laparotomy

Hypotensive on admission

Age $\geq 65$

Acute kidney injury-complication

Congestive heart failure-comorbidity

Myocardial infarction-complication

ARDS: Acute respiratory distress syndrome; ISS: Injury severity score.

\begin{tabular}{|c|c|c|}
\hline OR & $\mathbf{9 5 \%} \mathbf{C l}$ & $\mathbf{p}$ \\
\hline 0.31 & $0.18-0.53$ & $<0.001$ \\
\hline 0.34 & $0.21-0.57$ & $<0.001$ \\
\hline 0.39 & $0.18-0.85$ & $<0.05$ \\
\hline 0.49 & $0.35-0.69$ & $<0.001$ \\
\hline 1.69 & $1.14-2.51$ & $<0.001$ \\
\hline 2.10 & $1.41-3.11$ & $<0.001$ \\
\hline 2.11 & $1.53-2.92$ & $<0.001$ \\
\hline 2.22 & $1.29-3.84$ & $<0.001$ \\
\hline 2.34 & $1.74-3.16$ & $<0.001$ \\
\hline 3.66 & $2.47-5.42$ & $<0.001$ \\
\hline 3.96 & $2.84-5.50$ & $<0.001$ \\
\hline 5.32 & $2.07-13.69$ & $<0.05$ \\
\hline 6.49 & $2.19-19.27$ & $<0.05$ \\
\hline
\end{tabular}

Table 5. Analysis of clinical outcomes in trauma patients with and without an unplanned return to the operating room

\begin{tabular}{|c|c|c|c|}
\hline Outcome & $\begin{array}{c}\text { - uROR } \\
(n=2290)\end{array}$ & $\begin{array}{c}+ \text { uROR } \\
(n=6698)\end{array}$ & $p$ \\
\hline LOS days, median (IQR) & $3.0(4)$ & $18.0(21)$ & $<0.001$ \\
\hline ICU days, median (IQR) & $3.0(4)$ & $10.0(15)$ & $<0.001$ \\
\hline Ventilator days, median (IQR) & $3.0(7)$ & $8.0(13)$ & $<0.001$ \\
\hline \multicolumn{4}{|l|}{ Complications, n (\%) } \\
\hline Acute kidney injury & $22.774(0.7 \%)$ & $723(7.8 \%)$ & $<0.001$ \\
\hline ARDS & $28.466(0.8 \%)$ & $559(6.0 \%)$ & $<0.001$ \\
\hline Deep vein thrombosis & $25.911(0.8 \%)$ & $869(9.4 \%)$ & $<0.001$ \\
\hline Pulmonary emboli & $11.055(0.3 \%)$ & $310(3.3 \%)$ & $<0.001$ \\
\hline Surgical site infection & $5382(0.2 \%)$ & $435(4.7 \%)$ & $<0.001$ \\
\hline Urinary tract infection & $49.157(1.4 \%)$ & $840(9.1 \%)$ & $<0.001$ \\
\hline Myocardial infarction & 7957 (0.2\%) & $79(0.9 \%)$ & $<0.001$ \\
\hline Compartment syndrome & $7358(0.2 \%)$ & $472(5.1 \%)$ & $<0.001$ \\
\hline Pneumonia & 71.001 (2.1\%) & $1812(19.5 \%)$ & $<0.001$ \\
\hline Severe sepsis & $10.866(0.3 \%)$ & $705(7.6 \%)$ & $<0.001$ \\
\hline Mortality, n (\%) & $125.041(3.7 \%)$ & $1090(11.8 \%)$ & $<0.001$ \\
\hline
\end{tabular}

Most of the patients with UROR in our study were involved in blunt trauma. In support of previous reports, we demonstrate that blunt trauma carries a higher risk for mortality compared to penetrating trauma (13-17). A blunt mechanism of injury has the potential for multi-system injury and often involves TBI, which is considered one of the leading causes of death in trauma patients (18-20). Almost half the patients in our study with blunt trauma undergoing $\mathrm{UROR}$ had an accompanying TBI and nearly $60 \%$ of blunt trauma patients undergoing UROR that died had a TBI diagnosis. Furthermore, blunt trauma patients with UROR had a significantly higher rate of extremity fractures (64.9\% vs. 24.2\%) when compared to patients with UROR after penetrating trauma, which may predispose them to more bleeding. Femur fractures undergoing surgical fixation require, on average, more 
than three units of packed red blood cells due to peri-operative blood loss (21). Lastly, the trajectory of a penetrating injury is often easily found upon surgical exploration allowing for the early identification of all significant injuries. Patients with blunt trauma may have an occult injury without other surrounding associated injuries leading to increased mortality associated with delays in diagnosis (22-24).

Thoracic trauma has been shown to be involved in up to $50 \%$ of trauma-related deaths (25-27). In our study, we were able to demonstrate that trauma patients enduring UROR for RT had higher risk for mortality compared to patients undergoing UROR for RL. A previous study has demonstrated hemorrhage as the predominant factor requiring uROR for RT (2). Since hemorrhage is also the number one cause of mortality in trauma patients in general, it follows that UROR for RT had a higher mortality rate compared to those who underwent RL (28). Pujol et al. have reported that technical skills and expertise contribute to UROR and therefore, this may be a factor contributing to the increased mortality rate as well (29). From 2007-2015, there were 137.575 patients who underwent exploratory laparotomy in the NTDB while only 21.579 cases of exploratory thoracotomy were reported. A possible explanation for increased mortality in the RT group is that trauma surgeons have less experience working in the chest. Additional studies stratifying outcomes of UROR based on the operating surgeon's volume of thoracotomy cases appears warranted.

The overall mortality rate in our study population of trauma patients undergoing UROR was $11.8 \%$, which is significantly lower than the reported mortality rate in general surgery patients undergoing UROR (33.7\%) (3). These populations are quite different and the reason for this disparity is undoubtedly multifactorial. Some possible explanations include that the median age of trauma patients with UROR in the NTDB was lower than the aforementioned general surgery cohort (45 vs. 61 years), and the nature of the reason of the $U R O R$ may be very different (i.e. hemorrhaging trauma patients versus infection) (3).

The rate of UROR may be useful for comparison of hospital outcomes and for identifying opportunities for quality improvement (30). Our study identified an alarming trend of increased annual incidence of UROR. This is concerning as UROR poses a financial burden on the patient and a strain on hospital resources. An UROR has been shown to be associated with an eightfold increase in hospital readmission (31). In order for UROR to be a comparable metric across institutions, data collection must include documentation of the surgical findings at re-exploration, as well as the interventions performed. Only with this data can a comparison of results between centers yield meaningful quality improvement by demonstrating how high performing centers can achieve improved outcomes comparatively to low performing centers.

\section{Study Limitations}

There are several limitations to our study including those inherent to retrospective large databases such as participation being voluntary and coding error, which may lead to misclassification bias due to the under-reporting of pre-existing medical conditions and complications. Furthermore, our analysis was restricted to data fields available in the NTDB and were subject to input error. We were also missing important data such as timing of the index operation and reason for and time of $\mathrm{UROR}$. Therefore, adjustment for these potential confounders was not possible. Finally, because this was an observational study, the role of unmeasured or unobserved confounding variables cannot be excluded.

\section{CONCLUSION}

Trauma patients undergoing UROR appears to be on the rise. Most patients are involved in a blunt mechanism. Multiple predictors were identified for risk of $\mathrm{UROR}$, but the strongest risk factor was compartment syndrome. Both a blunt (compared to penetrating) mechanism and RT (compared to RL) are independent risk factors for mortality in patients undergoing $U R O R$. The overall mortality in trauma patients undergoing $U R O R$ is less than emergency general surgery patients undergoing UROR. Future prospective research regarding UROR in all trauma patients appears warranted to better elucidate the exact causes and interventions to prevent and/or successfully treat $U R O R$ in trauma patients.

Ethics Committee Approval: This study was approved by the Institutional Review Board at the University of California, Irvine.

Informed Consent: This research involved humans. However, since this retrospective study was performed using a national database with deidentified patients, risk to participants is minimal. There is no consent required.

Peer-review: Externally peer-reviewed.

Author Contributions: Consept - A.G., S.S., J.N.; Design - A.G., S.S., J.N.; Supervision - J.N.; Data Collection and/or Processing - A.G., T.D.; Analysis and Interpretation - A.G., S.S., V.G., A.D., V.J., T.D., N.B., J.N.; Literature Search - A.G., J.N.; Writing Manuscript - A.G.; Critical Reviews - A.G., S.S., V.G., A.D., V.J., N.B., T.D., J.N.

Conflict of Interest: The authors have no conflicts of interest to declare.

Financial Disclosure: The authors declared that this study has received no financial support.

\section{REFERENCES}

1. Ricciardi R, Roberts PL, Read TE, Marcello PW, Hall JF, Schoetz DJ. How often do patients return to the operating room after colorectal resections? Colorectal Dis 2012; 14:515-21. [CrossRef]

2. Foroulis CN, Kleontas A, Karatzopoulos A, Nana C, Tagarakis G, Tossios $P$, et al. Early reoperation performed for the management of complications in patients undergoing general thoracic surgical procedures. J Thorac Dis 2014; 6(Suppl 1): S21-31. 
3. Guevara OA, Rubio-Romero JA, Ruiz-Parra Al. Unplanned reoperations: is emergency surgery a risk factor? A cohort study. J Surg Res 2013; 182: 11-6. [CrossRef]

4. Waibel BH, Rotondo MM. Damage control surgery: it's evolution over the last 20 years. Revista do Colegio Brasileiro de Cirurgioes. 2012; 39: 314-21. [CrossRef]

5. Bellamy RF, Zajtchuk R, Buescher TM. Conventional warfare: ballistic, blast, and burn injuries: Walter Reed Army Institute of Research, Walter Reed Army Medical Center; 1991.

6. Stewart KC, Urschel JD, Nakai SS, Gelfand ET, Hamilton SM. Pulmonary resection for lung trauma. Ann Thorac Surg 1997; 63: 1587-8. [CrossRef]

7. Surgeons ACo. National Trauma Data Bank. American College of Surgeons. 2016.

8. Vles WJ, Veen EJ, Roukema JA, Meeuwis JD, Leenen LP. Consequences of delayed diagnoses in trauma patients: a prospective study. J Am Coll Surg 2003; 197: 596-602. [CrossRef]

9. Reid DC, Henderson R, Saboe L, Miller JD. Etiology and clinical course of missed spine fractures. J Trauma 1987; 27: 980-6. [CrossRef]

10. Houshian S, Larsen MS, Holm C. Missed injuries in a level I trauma center. J Trauma 2002; 52: 715-9. [CrossRef]

11. Konda SR, Kester BS, Fisher N, Behery UA, Lrespo AM, Egol KA. Acute compartment syndrome of the leg. J Orthop Trauma 2017; 31(Suppl 3): S17-S8. [CrossRef]

12. DePasse JM, Sargent R, Fantry AJ, Bokshan SL, Palumbo MA, Daniels AH. Assessment of malpractice claims associated with acute compartment syndrome. J Am Acad Orthop Surg 2017; 25: e109-e13. [CrossRef]

13. Goris RJ, Draaisma J. Causes of death after blunt trauma. J Trauma 1982; 22: 141-6. [CrossRef]

14. Peterson RJ, Tepas JJ, Edwards FH, Kissoon N, Pieper P, Ceithaml EL. Pediatric and adult thoracic trauma: age-related impact on presentation and outcome. The Annals of thoracic surgery. 1994; 58: 14-8. [CrossRef]

15. Ghorbani P, Falkén $M$, Riddez $L$, Sundelöf $M$, Oldner A, Strömmer $L$. Clinical review is essential to evaluate 30-day mortality after trauma. Scand J Trauma Resusc Emerg Med 2014; 22: 18. [CrossRef]

16. Moodley NB, Aldous C, Clarke DL. An audit of trauma-related mortality in a provincial capital in South Africa. S Afr J Surg 2014; 52(4): 101-4. [CrossRef]

17. Chiara O, Scott JD, Cimbanassi S, Marini A, Zoia R, Rodriguez A, et al. Trauma deaths in an Italian urban area: an audit of pre-hospital and in-hospital trauma care. Injury 2002; 33: 553-62. [CrossRef]
18. Shackford SR, Mackersie RC, Holbrook TL, Davis JW, HollingsworthFridlund P, Hoyt DB, et al. The epidemiology of traumatic death. A population-based analysis. Arch Surg 1993; 128: 571-5. [CrossRef]

19. Blennow K, Brody DL, Kochanek PM, Levin H, McKee A, Ribbers GM, et al. Traumatic brain injuries. Nat Rev Dis Primers 2016; 2: 16084. [CrossRef]

20. Chiara O, Scott JD, Cimbanassi S, Marini A, Zoia R, Rodriguez A, et al. Trauma deaths in an Italian urban area: an audit of pre-hospital and in-hospital trauma care. Injury 2002; 33: 553-62. [CrossRef]

21. Kajja I, Bimenya G, Eindhoven B, ten Duis HJ, Sibinga C. Blood loss and contributing factors in femoral fracture surgery. Afr Health Sci 2010; 10.

22. Sung CK, Kim KH. Missed injuries in abdominal trauma. J Trauma 1996; 41:276-8. [CrossRef]

23. Crookes BA, Shackford SR, Gratton J, Khaleel M, RatliffJ, Osler T. "Never be wrong": the morbidity of negative and delayed laparotomies after blunt trauma. J Trauma Acute Care Surg 2010; 69: 1386-92. [CrossRef

24. Eren B, Türkmen N, Gündoğmuş Ü. Delayed spleen rupture after blunt abdominal trauma (case report). Georgian Med News 2012; 22-4.

25. Lema MK, Chalya PL, Mabula JB, Mahalu W. Pattern and outcome of chest injuries at Bugando Medical Centre in Northwestern Tanzania. J Cardiothorac Surg 2011; 6: 7. [CrossRef]

26. Veysi VT, Nikolaou VS, Paliobeis C, Efstathopoulos N, Giannoudis PV. Prevalence of chest trauma, associated injuries and mortality: a level I trauma centre experience. Int Orthop 2009; 33: 1425-33. [CrossRef]

27. Virgos Senor B, Nebra Puertas AC, Sanchez Polo C, Broto Civera A, Suarez Pinilla MA. [Predictors of outcome in blunt chest trauma]. Arch Bronconeumol 2004; 40: 489-94. [CrossRef]

28. Curry N, Hopewell S, Doree C, Hyde C, Brohi K, Stanworth S. The acute management of trauma hemorrhage: a systematic review of randomized controlled trials. Critical Care 2011; 15: R92. [CrossRef]

29. Pujol N, Merrer J, Lemaire B, Boisrenoult P, DesmoineauxP, Oger P, et al. Unplanned return to theater: A quality of care and risk management index? Orthop Traumatol Surg Res 2015; 101: 399-403. [CrossRef]

30. Birkmeyer JD, Hamby LS, Birkmeyer CM, Decker MV, Karon NM, Dow RW. Is unplanned return to the operating room a useful quality indicator in general surgery? Arch Surg 2001; 136: 405-11. [CrossRef]

31. Ali TZ, Lehman EB, Aziz F. Unplanned return to operating room after lower extremity endovascular intervention is an independent predictor for hospital readmission. J Vasc Surg 2017; 65: 1735-44.e2. [CrossRef] 


\title{
ORIJINAL ÇALIŞMA-ÖZET
}

Turk J Surg 2019; 35 (1): 54-61

\section{Travma hastalarında plansız ameliyathaneye dönüş analizi}

\author{
Areg Grigorian ${ }^{1}$, Sebastian Schubl ${ }^{1}$, Viktor Gabriel ${ }^{1}$, Austin Dosch ${ }^{1}$, Victor Joe ${ }^{1}$, Nicole Bernal ${ }^{1}$, Taimoore Dogarr ${ }^{1}$, Jeffry Nahmias ${ }^{1}$
}

${ }^{1}$ California Üniversitesi, Irvine, Surgery, Orange, ABD

\section{ÖZET}

Giriş ve Amaç: Hasar kontrol cerrahisi geçiren travma hastalarında ameliyathaneye planlı bir dönüş olabilir. Bunun aksine, travmada plansız ameliyathaneye dönüşler (PAD) hakkında çok az şey bilinmektedir. Bu çalışmanın amacı, travma hastalarında PAD risk faktörlerini belirlemekti. Ayrıca, plansız ameliyathaneye dönüşlü künt travma hastalarının plansız ameliyathaneye dönüşlü penetran travma hastalarına kıyasla daha yüksek mortalite oranına sahip olduğu varsayımında bulunduk. Buna ek olarak, torakotomi yapılan PAD travma hastalarının laparotomi yapılan hastalara oranla daha yüksek mortaliteye sahip olduğu da öne sürülmüştür.

Gereç ve Yöntem: 2011-2015 yılları arasını kapsayacak şekilde Ulusal Travma Veri Bankasının plansız ameliyathaneye dönüşlü erişkin hastaların verileri üzerine geriye dönük analiz yapıldı.

Bulgular: 3.447 .320 hasta içerisinde 9269 (\%0.2)'unun plansız ameliyathaneye dönüşlü hastalar olduğu belirlendi. Çok değişkenli lojistik regresyon analizinde, kompartıman sendromunun $(\mathrm{OR}=10.50, \mathrm{Cl}=9.35-11.78, \mathrm{p}<0.001)$ en güçlü bağımsız risk faktörü olduğu 27 bağımsız risk faktörü saptandı. Reinsizyon laparotomiye kıyasla reinsizyon torakotomide de olduğu gibi $(\mathrm{OR}=2.22, \mathrm{Cl}=1.29-3.84$, $\mathrm{p}<0.001)(\mathrm{penetran}$ mekanizmaya kıyasla) künt mekanizma, plansız ameliyathaneye dönüşlü hastalarda daha yüksek mortalite riski ile ilişkiliydi.

Sonuç: Travmada PAD için en güçlü risk faktörü kompartıman sendromudur. Plansız ameliyathaneye dönüşlü hastalarda hem penetran mekanizmaya kıyasla künt mekanizma hem de reinsizyon laparotomiye kıyasla reinsizyon torakotomi bağımsız risk faktörlerini oluşturmaktadır.

Anahtar Kelimeler: Plansız ameliyathaneye dönüş, ameliyathaneye dönüş, reinsizyon torakotomi, reinsizyon laparotomi, travma

Doi: $10.5578 /$ turkjsurg.4182 